\title{
THE LLOYD'S LITIGATION
}

\author{
Alan MacKenzie*
}

The purpose of this article is to provide a general background to the recent spate of litigation generated within the Lloyd's market. It is intended to provide an overview of the more important categories of cases, and of some of the more important decisions. It is not intended to deal with all the relevant decisions, or provide a detailed review or analysis of those decisions which are discussed.

\section{THE STRUCTURE OF LLOYD'S}

Lloyd's is not an insurance company. It is not a single entity. It is a market. Every member ("Name") carries on business on his or her own account. As Lloyd's Act 1982 puts it, every Lloyd's policy must be underwritten with several liability "each underwriting member for his own part and not one for another". 1

The Names are grouped into syndicates. Each Name is, typically, a member of several syndicates. The business is written for each syndicate by an underwriter, who carries on business in the "Room" at Lloyd's. Because the Names do not actually attend to the insurance business which is conducted on their behalf, the concept of agency is fundamental to the operation of Lloyd's.

There are two types of agents:

(i) Members' agents: The prime role of a members' agent is to advise and administer a Name's Lloyd's affairs. It does not actually conduct the underwriting. Its function is to advise the Name as to the syndicates in which it considers that Names should participate and to find places on the syndicates.

(ii) Managing agent: The managing agent is responsible for the management of the syndicates. It appoints the underwriter who actually accepts the business. It also handles claims and administrations for the syndicate.

* Barrister and Solicitor of the High Court of New Zealand.

1 Ch xiv, s 8(1). 
Some agents act as combined members'/managing agents. When that occurs, there will be Names on a syndicate whose members' agent is the combined members' /managing agent. Such Names are referred to as "Direct Names". There will also usually be Names on the syndicate whose affairs are managed by other members' agents. These are referred to as "Indirect Names". All Names whose affairs are managed by a members' agent are Indirect Names, on syndicates managed by managing agents, or combined agents.

The terms of the agency relationships are regulated by Lloyd's. Until 1990, each Name entered into an agency agreement with his or her members' agent. That governed the relationship between the Name and the members' agent. If the agent was a combined agent, then the agreement also governed the relationship between the Direct Names and the combined agent acting in its capacity as managing agent. For Indirect Names, the members' agent entered into a sub-agency agreement with the managing agent for each syndicate, appointing the managing agent its sub-agent in respect of the Name's participation in that syndicate. Until 1987, there were no prescribed forms of underwriting agency or subagency agreements, but from 1987 there were standard forms of agency agreement and subagency agreement prescribed by Lloyd's.

From 1990, the position changed. Lloyd's prescribed new forms of agency agreement. The structure of the arrangements was changed. Each Name was required to have a separate agreement with each of his or her members and managing agents. The Name had a direct contract with each of the managing agents to whom he or she gave underwriting authority.

\section{INSURANCE LOSSES IN THE 1980s}

\section{A General Losses}

The late 1980s were a bad period for insurers worldwide. There were two major factors underlying this; major disasters and a rash of "long-tail" claims. ${ }^{2}$

\section{Major disasters}

The late 1980s was an exceptionally bad period for major disasters, both natural and man-made. In the period 1987-1992, insurance markets worldwide were hit by a succession of major catastrophe losses, on an unprecedented scale. These included:
(a) $1987 \quad$ North European wind storms
(b) $1988 \quad$ Piper Alpha
Hurricane Gilbert

2 A term used to describe a risk that may have claims arising long after the risk has ceased to attach. 
(c) 1989 Hurricane Hugo

San Francisco earthquake

Exxon Valdez

Phillips Petroleum

(d) $1990 \quad$ North European storms

(e) 1992 Hurricane Andrew

The total insured losses from these and other disasters were enormous.

\section{2 "Long-tail" claims}

The insurance industry was also seriously affected by a rash of "long-tail" claims, mainly from North American liability business, in respect of the claims arising from asbestosis, and from the cost involved in cleaning up polluted sites, under US environmental legislation. These impacted on the insurance industry because typically liability policies had been written on an "occurrence" basis.

When claims for asbestosis were made against manufacturers, users and installers of asbestos products, those defendants claimed indemnity under the insurance policies in force when the exposure took place. Decisions of US courts ${ }^{3}$ held that any insurer who had covered a party at any time during the plaintiff's exposure to asbestos could be held liable.

For pollution liabilities, the scenario is that manufacturers of chemicals and pollutants were increasingly required, by stricter environmental laws, to clean up sites polluted by their activities. They sought to claim indemnity for these costs from their liability insurers, under the policies in force at the time when the polluting activity was carried on. These claims have been resisted by insurers, and much litigation over liability has resulted. There are ongoing attempts to reach a legislated settlement by the "Superfund" legislation in the US. ${ }^{4}$ It is important to note that many of the "losses" in this category are reserves for potential claims, rather than actual claims.

Litigation, in many cases, is ongoing, particularly in US courts, and insurers have had some significant successes in limiting the extent of policy coverage, reducing the potential of this type of liability. Prominent cases include those relating to Shell Oil for pollution at its Rocky Mountains facility, and Lockheed Corporation for pollution at Burbank, California.

3 Eg Insurance Co of North America $v$ Forty-Eight Insulations Inc $633 \mathrm{~F} 2 \mathrm{~d} 1212$ (6th Cir, 1988), modified, $657 \mathrm{~F} 2 \mathrm{~d}$ 814 (6th Cir), cert denied, 454 US 1109 (1981); Cole $v$ Celotex Corp 599 So 2d 1058, 1060 (La 1992).

4 Comprehensive Environmental Response Compensation Liability Act 1990 (CERCLA) 42 USC. 


\section{$B$ The Losses at Lloyd's}

Most major insurers suffered large losses in the late 1980s. Lloyd's was no exception. In the years from 1988 to 1992 , its combined losses totalled some $£ 8$ billion. This has been followed by profits of over $£ 1$ billion in 1993, and good profits are expected for the still open 1994 and 1995 years.

Broadly, the major losses at Lloyd's can be grouped under two main headings, essentially arising from the two factors referred to above, namely the large number of disasters, and the long-tail US liabilities. Because of the unique structure of Lloyd's, and the nature of its business, these impacted on Lloyd's in particular ways.

\section{The LMX spiral}

The large number of catastrophes affected all insurers. Their impact on Lloyd's and the London market was particularly severe, because of what has become known as "the LMX Spiral". LMX (London market excess of loss) is a term used to describe a particular category of reinsurance business. It is written in the London market, including both Lloyd's and London companies. Excess of loss reinsurance is designed to cap an insurer's exposure to a very large individual risk, or to an aggregation of risks which are exposed to the same event. The insurer will determine what is the maximum loss that it wishes to retain for its own account. It will then reinsure its liability for a single loss above that limit, or an aggregation of losses from a single event above that limit. That reinsurance will normally be placed in layers. Excess of loss insurance in the high layers is referred to as catastrophe insurance, as it will only be called upon in the event of a catastrophe.

This excess of loss reinsurance is thus part of the mechanism by which risks are spread by insurance. However, because of its specialist nature, and the relatively small number of insurers carrying on this type of business, what has been referred to as "the LMX Spiral" developed. Insurers who wrote excess of loss ("XL") cover would in turn take out XL reinsurance cover themselves. Those reinsurers would in turn take out their own XL reinsurance. The small size of the market meant that risks tended to be passed around a relatively small number of players. For instance, a company which had reinsured its own catastrophe losses on an XL basis with another reinsurer might find that it was in turn writing some reinsurance for the reinsurers. A description of the spiral is contained in the judgment of Phillips J in Deeny $v$ Gooda Walker Ltd as follows: ${ }^{5}$

Many syndicates which wrote $X L$ cover took out $X L$ cover themselves. Those who reinsured them were thus writing $X L$ on $X L$. They, in their turn, frequently took out their own XL cover. There thus developed among the syndicates and companies which wrote LMX

5 Unreported, 4 October 1994, Queens Bench Division, Commercial Court, 1993 Folio No 335. 
business a smaller group that was largely responsible for creating a complex intertwining network of mutual reinsurance, which has been described as the spiral. When a catastrophe led to claims being made by primary insurers on their $\mathrm{XL}$ covers, this started a process whereby syndicates passed on their liabilities, in excess of their own retentions, under their own XL covers from one to the next, rather like a multiple game of pass the parcel. Those left holding the liability parcels were those who first exhausted their layers of $\mathrm{XL}$ reinsurance protection.

So far as the individual syndicate was concerned, the effect of the spiral was to magnify many times the impact of a particular loss. That is because claims were repeatedly made in respect of the same loss as it circulated in the spiral. I was told that claims in respect of the Piper Alpha loss exceeded by a multiple of about 10 the net loss that was covered on the London market.

This gearing effect did not, of course, result in an ultimate payment of a greater indemnity than the initial loss. As the loss passed through the spiral, however, it impacted repeatedly on successive layers of reinsurance cover, and ultimately concentrated on those reinsurers who found their cover exhausted.

Because catastrophe reinsurance is, by its nature, called upon only when there is a catastrophe, XL reinsurers will make good profits in times when there are few catastrophes, natural or man-made. Conversely, they will suffer severely when there are a large number of catastrophes which, as has been shown above, occurred in the late 1980s. The effect of the spiral was that those catastrophe losses, rather than being spread among a large number of reinsurers, became concentrated in a relatively small number of reinsurers. This included both some Lloyd's syndicates, and companies operating in the London market.

\section{Long-tail liabilities}

The effect of the asbestos and pollution claims has already been described. In effect, insurers of liability policies issued years or even decades ago became subjected to claims on those policies. This phenomenon affected all insurers. Because of the structure of Lloyd's, it impacted on Lloyd's in a particular and unique way.

As explained above, each Name carries on business on his or her own account. The syndicate is in effect a collection of sole traders. The syndicate has no ongoing existence, and is in legal terms, an annual venture. Lloyd's has a three year accounting cycle. At the end of each three year period, profits for the particular syndicate year can be determined. There will however, for most categories of business, still be claims unresolved, and potential claims still to come home to roost. Provision needs to be made to meet those claims, to the extent that they cannot be adequately provided for by reserves. However, there is a need to obtain finality for the Names who have written on that particular syndicate for that particular year. 
The way in which these two conflicting objectives have traditionally been achieved at Lloyd's is for the syndicate in year one to enter into a contract of reinsurance with the syndicate in year two, whereby the syndicate in year two takes over (for a premium) any remaining liabilities of the Names in respect of syndicate year one. At the end of syndicate year two, any remaining liabilities of the Names in respect of that syndicate year (which includes the liabilities in respect of syndicate year one) are reinsured into syndicate year three, and so on from year to year. This is called reinsurance to close.

The effect of this, over successive years, is that the liability to meet the claims which have surfaced many years later lies with the Names on the current syndicates. Because these claims were not anticipated, and all concerned thought, until the asbestos and pollution problems manifested themselves, that the policies concerned were long dead, the reinsurance to close premium for those claims would have been negligible. Thus, the Names at Lloyd's, when the problem surfaced, inherited problems from the previous business in respect of which they had in effect received virtually no premium.

Obviously, once the problem came to be known, it would not be possible for the syndicate in the year in which the problem manifested itself to obtain reinsurance to close with the syndicate for the following year. The underwriter for the syndicate in the following year would be aware of the potential problem and would either not reinsure, or do so only at a very large premium.

Unless the syndicate can obtain reinsurance to close, the Names on that syndicate will remain liable for the business written by that syndicate (including the reinsurance of all preceding years of that syndicate). That syndicate year is then referred to as an "open year" and the Names on it remain committed until its liabilities are finally settled.

\section{THE LITIGATION}

The various problems described above, and others, have led, because of the unique structure of Lloyd's, to some particularly difficult legal issues which have been the subject of much litigation, through the commercial court in London. When the scale of the potential Lloyd's actions became clear, that court decided to treat the Lloyd's litigation as one category, with at least one dedicated commercial court judge. This was originally Saville J, now Cresswell J. Other judges, particularly Phillips J, have been involved in hearing the trials. The following is a brief description of some of the more important, and interesting, cases. 
The court has categorised the litigation under six main subject headings: ${ }^{6}$

(i) LMX cases;

(ii) Long-tail cases, including:

(a) run off contracts; and

(b) reinsurance to close cases;

(iii) Personal stop loss cases;

(iv) Portfolio selection cases;

(v) Solvency cases/central fund litigation;

(vi) Other cases (including issues involving Lloyd's and auditors).

In addition, there have been a number of other proceedings, in other courts and in other jurisdictions, which do not fall within these particular categories.

One of the issues which arises in the various claims, particularly in the LMX cases and the long-tail cases, against members' agents and managing agents, is whether there can be concurrent liability in contract and in tort. This is important, particularly in relation to limitation periods. That issue was tried as a preliminary issue in a number of the actions and proceeded to the House of Lords in Henderson $v$ Merrett. ${ }^{7}$ It was held that there could be concurrent liability in contract and in tort, so that a breach of a duty by either a members' agent or a managing agent to exercise reasonable care in the management of a Name's affairs, or in underwriting, might give rise to a cause of action either in contract for breach of the agency agreement, or in tort.

\section{A The LMX Cases}

Several major cases have proceeded to trial in respect of Names on LMX syndicates. These have involved claims by the Names on various LMX syndicates against the managing agents of those syndicates, and against their members' agents, alleging negligent underwriting. The following are some of the more important decisions:

\section{Deeny $v$ Gooda Walker Ltd}

The main judgment of Phillips J was delivered on 4 October 1994. The claim related to LMX underwriting in respect of five specific catastrophes. The judgment contains a useful

6 The Commercial Court adopted a case management plan in July 1993 based on these categories.

$7 \quad$ [1994] 3 All ER 506.

$8 \quad$ Above $\mathbf{n} 5$. 
description of the LMX market, and of the underwriting principles which apply to the writing of LMX business. It was held that the underwriters had been negligent in a number of specific respects involving:

(a) failure to plan the underwriting properly, in relation to the level of exposure;

(b) failing to adequately monitor the aggregates and probable maximum losses;

(c) failing to provide adequate reinsurance protection, with matching reinstatements; and

(d) failing to rate the business adequately - that is, to ensure the premium adequately reflected the risk.

The standard of skill and care applied was in essence the same as that habitually applied in the case of professional negligence claims against professionals. The judge therefore held that the plaintiffs were entitled to damages. He dealt with the approach to be adopted in assessing the damages, but did not in that judgment fix the level of those damages.

On the approach to be adopted on quantum, he considered, and rejected, the possibility of comparing the results of the syndicates involved in this case against a "paradigm syndicate" - that is, an assessment of the results a typical competent XL syndicate would have achieved. That was an approach which had been used earlier by a legal panel convened by Lloyd's to formulate an offer for settlement of the litigation. He held that this would be an artificial and unrealistic exercise. He adopted, in effect, an approach which held the plaintiffs entitled to recover all losses above those which would have been incurred if proper reinsurances had been in place.

There have been a number of further hearings, and judgments, clarifying various aspects of the judgment, and making further findings in respect of quantum. ${ }^{9}$

An important issue is whether the Gooda Walker plaintiffs, being the first to obtain judgment, should be able to enforce the judgment, which might exhaust the resources and insurance cover of some agents, before other plaintiffs, also with a claim against those agents, could have their claims heard. That has been called the "first past the post" issue. That issue was decided, essentially in favour of "first past the post", in Cox $v$ Bankside Agency Ltd. ${ }^{10}$

Another issue was whether the damages awarded were subject to tax, and so should be paid on a gross basis. This issue was decided by the House of Lords in Deeny $v$ Gooda

9 One of these is reported at [1995] 4 All ER 289.

10 [1995] 2 Lloyd's Rep 437. 
Walker Ltd, ${ }^{11}$ where it was held that the damages were a taxable receipt, and should therefore be paid on a gross basis.

\section{Arbuthnott $v$ Feltrim Underwriting Agencies Ltd ${ }^{12}$}

This is another LMX case. The issues were broadly similar to Gooda Walker. Negligence on the part of the underwriters was found, in several respects. There have been a number of other LMX cases, on broadly similar lines.

\section{B Long-Tail Cases}

These cases generally relate to underwriters who write reinsurance to close, or run off, business. Essentially, the issue is whether, at relevant times, they should have been aware of the possibility of the long-tail claims.

\section{Names on Pullbrook syndicates}

One of the first to go to trial was a claim by Names on Pullbrook syndicates. Judgment on certain issues of liability and quantum was delivered on 10 February 1995 . Both members' agent and managing agent were held liable, the managing agent in tort, the members' agent in contract but not in tort. However, many of the claims were held statute barred.

\section{Henderson $v$ Merrett Syndicates Ltd}

This judgment, delivered in October 1995 by Cresswell J, concerned the writing of a series of unlimited runoff contracts, and the wrongful closure of a number of syndicate years. The plaintiffs succeeded against the managing agency, the active underwriter, and the members' agents. Additionally, a claim against the auditors of the syndicate was also successful.

An important supplementary judgment, delivered in February 1996, dealt with issues of limitation, principles of calculation of damages, contribution between defendants and interim payment.

\section{Stop Loss Cases}

These are cases involving personal stop loss. This is a form of insurance taken out by many Names. It is, in effect, an XL insurance of an individual Name's liability. Cover is taken out for losses which exceed a specified sum.

11 [1996] 1 All ER 933.

12 Unreported, 10 March 1995, High Court (Phillips J). 
One important case, in respect of stop loss, is Lord Napier and Ettrick $v$ Hunter. ${ }^{13}$ This was an important case on subrogation generally. In this case, Names who had suffered losses and who had recovered under stop loss policies in respect of those losses, sued their agents, and settled that claim. The issue arose as to whether the stop loss insurers were entitled to a share of the settlement recoveries. The House of Lords held that the settlement recoveries were to be applied:

(a) in favour of the Name for any losses which were in excess of the stop loss cover;

(b) in favour of the stop loss insurers to the extent of their payment;

(c) any balance was to be paid to the insured in respect of that part of the loss which was below the level of the stop loss cover.

Another issue in that litigation was whether Lloyd's was entitled to retain, as part of the Premium Trust Deed funds which provide security for a Name's underwriting obligations, litigation recoveries from successful claims by Names against, for example, members' agents and managing agents. The Court of Appeal, in July 1996, has held that these recoveries are subject to the Premium Trust Deed.

\section{Portfolio Selection Cases}

These cases relate to claims against members' agents, in respect of the advice given to Names as to the syndicates in which they should participate.

\section{Brown $v$ KMR Services Ltd ${ }^{14}$}

This case related to two Names. One, who was held to be of limited means, and a cautious investor, was successful in a claim that he had been placed on several XL syndicates, without proper advice as to the degree of risk. He was held entitled to recover his losses on those syndicates.

The second, an independent-minded Name who made his own investment decisions, succeeded in his claim, on the basis that he was not given adequate warning of the dangers of the high risk XL syndicates. However, it was held that, had he been warned, he would still have participated in XL business, but to a lesser extent. The damages recoverable reflected that, and were reduced pro-rata. That Name appealed to the Court of Appeal, where the pro-rata reduction was varied. ${ }^{15}$

13 [1993] 1 All ER 385 (House of Lords).

14 [1994] 4 All ER 385 (Gatehouse J).

15 [1995] 4 All ER 598 (Court of Appeal). 


\section{Barrow $v$ Bankside Members Agency Ltd ${ }^{16}$}

In this case, the issue was whether a plaintiff, who had also been a plaintiff in Deeny $v$ Gooda Walker Ltd, was precluded from bringing a subsequent portfolio selection case. It was argued that to do so infringed the rule that parties to litigation must bring forward their whole case, and cannot bring subsequent proceedings in respect of a claim which could have been included in the earlier proceedings. The Court of Appeal allowed the case to proceed, on the grounds that the portfolio selection case could not reasonably have been litigated in the earlier proceedings. However, since the plaintiff could not recover twice for the same damage, a stay was granted pending the outcome of the Gooda Walker appeal.

\section{E Central Fund Litigation}

A further issue involving Lloyd's relates to the Central Fund. There is a long chain of security for the obligations under a Lloyd's policy. It includes premium trust funds, funds held at Lloyd's belonging to individual Names, and individual Names' own assets. Finally, in the event that an individual Name defaults on his or her liabilities, there is a Central Fund from which claims are paid. Thus, if a Name fails to pay his or her losses, these will be paid by Lloyd's from the Central Fund, and Lloyd's will then seek to recover these funds from the Names. This has given rise to litigation over a number of issues.

In Marchant $\mathcal{E}$ Eliot Underwriting Ltd $v$ Higgins ${ }^{17}$ subsequently affirmed by the Court of Appeal, the Court upheld the "pay now sue later" clause in the standard agency agreement and Lloyd's membership documentation, which requires Names to pay losses, without setoff or counterclaim for claims for damages.

In Lloyd's $v$ Clementson, ${ }^{18}$ a defence was raised that Lloyd's was prevented from recovering, from Names, money paid on their behalf from the Central Fund, because certain of Lloyd's arrangements were alleged to be contrary to European union law under the Treaty of Rome, that defence was rejected.

\section{F Litigation in respect of Bank Guarantees and Letters of Credit}

Names at Lloyd's must lodge a prescribed level of funds at Lloyd's as security for their underwriting. They are able to do this by means of a bank guarantee or letter of credit. That is an instrument by a London bank in favour of Lloyd's, under which the bank undertakes to pay Lloyd's a prescribed amount in the event of a default by the Name on his or her underwriting obligations. The London bank will then normally have a back to back

16 [1996] 1 Lloyd's Rep 278 (Court of Appeal).

17 [1996] 1 Lloyd's Rep 313, (Rix J).

18 Unreported, June 1996, (Cresswell J). 
arrangement with the Name's own bank in the country where the Name resides, and that bank will have security from the Name for any liability under the guarantee.

When the extent of the losses at Lloyd's became apparent, many Names, both in England and elsewhere, attempted to resist drawdowns of the bank guarantees. Litigation was commenced in a number of jurisdictions. Notably, there were cases in the US, Canada, Australia and New Zealand.

The main New Zealand litigation is Society of Lloyd's $v$ Hyslop. ${ }^{19}$ In that case, a New Zealand Name brought proceedings against Lloyd's and her members' agent, and her bank, seeking to prevent drawdown. A number of causes of action were pleaded including:

(a) misrepresentation;

(b) breach of the Fair Trading Act 1986;

(c) breach of the Securities Act 1978;

(d) breach of a duty of care;

(e) breach of contract.

Application was made to strike out the proceedings on jurisdictional grounds, and essentially on the basis that the Lloyd's Agency Agreements and associated documentation contain London jurisdiction clauses.

In the High Court, all but one of the causes of action were struck out. Holland J permitted the cause of action alleging that membership of Lloyd's involved the offer of a security, thus requiring compliance with the Securities Act, to be litigated in New Zealand.

On appeal, that cause of action too was struck out. It was held that Lloyd's membership did not involve an offer of securities to the public. It was also held that on jurisdictional grounds litigation in England was to be preferred.

Essentially similar decisions were reached in the other jurisdictions mentioned. The cases include:
(a) US:
Riley $v$ Kingsley Underwriting Agencies Ltd; ${ }^{20}$
(b) Canada:
Ash $v$ Lloyd's Corporation; ${ }^{21}$ and

19 [1993] 3 NZLR 135.

20969 F 2d 953 (1992).

21 (1992) 4 OR (3d) 755. 
(c) Australia: Williams $v$ The Society of Lloyd's. ${ }^{22}$

Attempts to prevent drawdowns in the UK courts were also unsuccessful.

\section{REINSURANCE CLAIMS}

Although not strictly part of the Lloyd's litigation under the case management system, there have been a number of significant reinsurance disputes between Lloyd's underwriters and reinsurers, often also within the Lloyd's market. These cases relate to issues such as:

(a) whether adequate disclosure has been made; ${ }^{23}$

(b) the effect of clauses requiring that insurance claims be actually paid before recovery from the reinsurer can be made; ${ }^{24}$ and

(c) the effect of clauses as to the number of claims, and "follow settlement" clauses. ${ }^{25}$

\section{$V$ RECONSTRUCTION AND RENEWAL}

To deal with the problems created by the large number of open years, and to resolve the mass of litigation, Lloyd's has been proceeding, since May 1995, with its massive Reconstruction and Renewal Plan. Essential elements of the plan are:

(a) The creation of the world's largest run off reinsurance company, Equitas, into which all liabilities of all Lloyd's syndicates for all years, 1992 and prior, will be reinsured, by a reinsurance to close.

(b) A settlement agreement, among all parties to the litigation, and other participants in the Lloyd's market, to settle all claims arising within the Lloyd's market for the period up to 1992, including all existing and future litigation involving such claims. This will include those claims which have already been litigated.

This Reconstruction and Renewal Plan has now been accepted by over ninety percent of the membership. In September 1996,it was declared unconditional by Lloyd's and the Department of Trade and Industry has confirmed the full authorisation of Equitas. This means that all of the litigation covered by the settlement agreement is now at an end. Lloyd's is now able to trade forward, unencumbered by the liabilities of the past. The Chairman,

22 [1994] 1 VR 274.

23 PCW Syndicates $v$ PCW Reinsurers [1996] 1 Lloyd's Rep 241.

24 Charter Reinsurance Co Ltd v Fagan [1996] 1 Lloyd's Rep 261.

25 Axa Reinsurance UK Ltd v Field [1996] 1 Lloyd's Rep 26. 
David Rowland, has described this as signalling "[T]he beginning of a new journey to consolidate this market's reputation as a centre of insurance excellence." 26

26 Lloyd's of London press release, dated 4 September 1996. 